\title{
Teoria Crítica e teorias educacionais: Uma análise do discurso sobre educação
}

\author{
Sueli Soares dos Santos Batista*
}

\begin{abstract}
RESUMO: Este artigo visa apresentar algumas reflexões sobre sociedade e educação pensadas a partir da Teoria Crítica que, especialmente, no pensamento de T. W. Adorno, postula a interpretação e a transformação da sociedade e do conhecimento por ela produzido como premissa básica de uma educação emancipatória. A crítica ao positivismo, a constatação das antinomias entre cultura e administração são instrumentos para a análise do construtivismo, da discussão sobre democratização do ensino e das formulações que estabelecem ligações imediatas entre relações interpessoais e democracia.
\end{abstract}

Palavras-chave: Teoria Crítica, educação, sociologia da educação, democratização do ensino, crítica ao positivismo

As propostas que, ao longo do tempo, têm procurado facilitar mais e mais a assimilação do conteúdo através de sua banalização afirmam a impotência do indivíduo frente a um todo aniquilador. Os métodos centrados no aluno, de um lado, ou no saber, de outro, polarizando-os, eliminam a tensão entre a cultura e a barbárie, o indivíduo e a sociedade e, em primeira instância, entre espírito e natureza.

Pretendemos lançar luzes sobre o problema da educação a partir de um ponto de vista menos centrado na prática pedagógica que, na concepção de Adorno (1972), de antemão, está sob suspeita:

* Doutoranda em Psicologia Escolar no Instituto de Psicologia - USP. Bolsista FAPESP. E-mail: adaomarques@usf.com.br. 
O problema da imanente falsidade da pedagogia reside em que recorta a coisa tratada à medida dos receptores, e não constitui um trabalho puramente objetivo pela coisa mesma. É mais um trabalho "pedagogizado". Já por esta razão deveriam os alunos sentir-se inconscientemente enganados. (...) Max Scheler disse uma vez que ele se comportou pedagogicamente pela sensível e única razão de que nunca havia tratado seus alunos de forma pedagógica. (p. 69)

O colapso do sistema e dos métodos educativos não se resolve simplesmente com reformas pedagógicas que têm se limitado na priorização da teoria ou da prática ou até mesmo na harmonização destas instâncias contraditórias. O esforço pedagógico, no sentido de veicular um conhecimento preestabelecido de forma também preestabelecida conforme o "nível" sociocognitivo dos alunos, está mais a serviço da amputação do pensamento do que de seu desenvolvimento.

Adorno corrobora a assertiva de Max Scheler ao considerar que se comportar pedagogicamente é abrir mão da pedagogia. Formação em graus sequer articulados entre si, em níveis escalonados por outrem, é, na verdade, o seu inimigo mortal. A tarefa pedagógica realizada na escola não é equivalente àquela supostamente realizada pela indústria cultural ao afirmar que adapta os "bens culturais" ao gosto dos clientes? Os padrões da indústria cultural são aceitos, geralmente, sem resistência, porque têm como ponto de partida não simplesmente as necessidades dos consumidores: tanto aquelas legítimas, que são reinscritas na ordem da reificação - havendo aí uma secreta cumplicidade -, mas também aquelas pré-moldadas (produzidas) pela reificação. A diferença, e talvez aí resida a fresta por onde possa entrar a luz, é que a escola, mesmo assimilando acriticamente a indústria cultural, não consegue ser tão convincente quanto. Esta inadequação deve ser aproveitada ao ponto de indústria cultural e escola, na abordagem dos conteúdos, serem a negação uma da outra. Se o espectador não deve ter necessidade de nenhum pensamento próprio, "o produto prescreve toda reação: não por sua estrutura temática - que desmorona na medida em que exige o pensamento - mas através de sinais" (Adorno e Horkheimer 1994, p. 129) - o filme sonoro é exemplar neste sentido -, a escola incentivando atividades em que o pensamento não possa ser evitado já se contrapõe à ordem das coisas.

Chegamos ao limite de nos questionar a serviço do que está a pedagogia e se ela é capaz de dar conta da formação daqueles que irão trabalhar profissionalmente na formação de outrem. E ainda se a formação e a ação 
pedagógica do professor não são antes a expressão da semiformação laborando pelo seu fortalecimento. Trata-se de uma formação realizada em parte, restrita à adaptação e integração do sujeito sem contudo proporcionarIhe os pressupostos para a emancipação. A "semiformação" é verdadeira e falsa ao mesmo tempo. É verdadeira para uma sociedade constituída a partir de uma socialização domesticadora. É falsa, pois, ao proporcionar a formação pela metade, não viabiliza seu objetivo fundamental (Adorno 1996).

Se as doutrinas pedagógicas historicamente se estruturaram e se desenvolveram em função da emergência da sociedade de classes, nascendo a escola no berço da hierarquização e a desigualdade econômica (Gadotti 1995, p. 23), quais são as possibilidades de uma educação emancipatória pensada a partir da pedagogia?

O professor é o mediador fragilizado entre o aluno e a instituição que dita as regras do jogo. Professor enquanto mediador, postura tão efusivamente defendida pelas pedagogias progressistas, na realidade, depõe contra a docência no sentido de ser uma atividade de circulação: o professor tem se tornado mais e mais um vendedor de conhecimentos (Adorno 1972, p. 69) cada vez mais desqualificado pela sociedade por não reverter para si mesmo os lucros prováveis desta negociação. A expressão mais adequada talvez fosse a de "revendedor", pois do montante em circulação adquire apenas uma ínfima porcentagem. Não estamos nos referindo apenas à questão salarial, que em si mesma é deprimente, mas às possibilidades que o professor encontra para "adquirir" a sua formação e a parcela de poder que lhe é concedida. Se conhecimento é poder, os dois termos desta equação the são negados.

O pior em tudo isto, em nosso entender, é que, enquanto agentes da formação cultural, os professores não se sintam nesta ação também se formando, mas deformando a si mesmos. É evidente que isso não decorre tão-somente da relação professor-alunos, mas da nossa relação com um conhecimento que visa mais domesticar que emancipar. Contudo há que se considerar que a pedagogia de braços dados com a semiformação - deformação - é apenas uma face das antinomias entre cultura e administração, que tem de ser levada em conta se pretendemos educar para a emancipação.

Adorno é muito feliz ao problematizar a necessidade escolar e sua inerente repressão à liberdade e à formação intelectual. Ao pensar sobre as administrações escolares, aponta para a corriqueira hostilidade que 
impõem ao trabalho científico dos professores devolvendo-os constantemente à terra.

Não vamos nem citar "hostilidade ao trabalho científico", mas algo ainda anterior, que seria o indisfarçado descontentamento perante as aulas não convencionais que busquem espaços e recursos alternativos. Não seria ousado afirmar que, mais do que hostilidade, há na prática escolar uma conspiração à liberdade e à formação cultural. A burocracia e o comodismo estão unidos nesta empreitada.

É evidente que a questão não é purificar simplesmente a instituição de ensino de todo caráter administrativo. Isso seria pressupor um isolamento onde há na realidade uma imbricação. Adorno (Adorno e Horkheimer 1971, p. 69) considera que, ao falar de cultura, fala-se também de administração. Pode-se dizer que as contradições entre cultura e administração são apenas aparentes. No próprio uso da palavra cultura - quando nos referimos à arte, religião, instituições -, há o caráter administrativo de reunir em um mesmo conceito atividades múltiplas e contraditórias.

O paralelo entre cultura e administração é semelhante ao moderno dualismo entre cultura e civilização: cultura enquanto algo "espiritual" e civilização como tudo o que se refere ao "material", mais especificamente à técnica. Para Adorno e Horkheimer (1969, p. 102), a administração é a expressão da cultura que não se realizou, da mesma forma que o fetiche da técnica inerente à nossa civilização é o substitutivo ortopédico das promessas ainda não concretizadas pela cultura. Pode-se subtrair das considerações de Adorno que a administração é um momento da cultura. Não há que se fazer simplesmente a oposição ou hierarquização entre as duas esferas que estão desde sempre entrelaçadas. Há que se considerar a contradição inerente da relação entre ambas: a cultura reivindica o particular frente à generalidade e a administração, como princípio da sua sobrevivência, representa e assegura os interesses do geral frente ao particular.

Adorno identifica a independização da administração perante a cultura, tornando-se um fim em si mesma: padrões externos, regras que não são inerentes à cultura, desrespeito às qualidades do objeto e uma falta de espontaneísmo em seus projetos que aniquila as suas finalidades. Esta extensão da competência administrativa é irracional, mas pode e deve ser diferente. Adorno (Adorno e Horkheimer 1971, p. 77) propõe uma política cultural que não se contente com a função de mero órgão administrativo, nem tampouco tenha a cultura como algo sacralizado, intocável e supérfluo. 
Estar a serviço do público e contra o público ao mesmo tempo. Em suma, manter uma postura dialética perante o que não é conciliável e não perder de vista a independência crítica frente ao poder e ao espírito da sociedade de consumo. Esta seria uma administração ilustrada, consciente de suas antinomias com a cultura que diz representar e fomentar.

Para Adorno (Adorno e Horkheimer 1971, p. 97), cultura e administração, por mais que estejam coisificadas, expressando o mundo totalmente administrado, sempre se remetem ao sujeito vivente que, fazendo uso da sua consciência espontânea ainda não aprisionada por inteiro, pode transformar o funcionamento das instituições. Se quem silencia o discurso da educação, instituindo o discurso sobre a educação, é a administração, resta a este "sujeito sobrevivente" (professores e estudantes) fazer ouvir a sua voz (Chauí 1979, pp. 27-29).

Esta "consciência espontânea" reivindicada por Adorno é por demais exigida do professor que, num esforço hercúleo, tem de aprender a vencer as vicissitudes do cotidiano escolar. $O$ que efetivamente o professor tem condições de fazer para transformar o quadro atual de fracasso escolar que é, em suma, o fracasso da sociedade e de seus pressupostos culturais? Este esforço hercúleo a que nos referimos tem sido avaliado no sentido de dizer um "sim" enfático à cegueira das políticas educacionais dos diversos governos que desfilam à frente da miséria cultural perene e absoluta. Isso fica claro na tentativa de diminuir o número de crianças evadidas da escola simplesmente eliminando a repetência. Parece que desistimos - de uma vez por todas - da formação cultural que seria um luxo, portanto o "lixo" nos basta. A perspectiva de mais crianças e por mais tempo na escola, num ponto de vista meramente quantitativo, pode ser chamada de "democratização"? O postulado da autonomia exige algo mais.

Considerar que a expansão da sociedade de consumo e a democratização do ensino - que são em si a mesma coisa - resultam na democracia é permanecer no terreno da dominação:

Dizer que a técnica e o nível de vida mais alto redundam sem mais em favor da formação cultural em virtude do que a formação cultural alcance a todos é uma pseudodemocrática ideologia de vendedor. (Adorno 1972b, p. 253)

Neste sentido, como se comporta a escola num mundo que se pretende democrático? O distanciamento da escola perante exigências 
imediatas da sociedade, ou seja, a sua tão propalada inadequação às leis do mercado, tem em si o aspecto promissor de se poder contrapor à reificação do pensamento. Resistindo aos preceitos pretensamente racionais de utilidade e eficiência, a escola pode produzir um conhecimento outro que reflita sobre o mundo totalmente administrado. Isso não quer dizer que se deva acomodar à idéia de inutilidade como necessidade - idéia esta originária de um conceito ingênuo de cultura. Para Adorno, renunciar à práxis possível é equivalente a neutralizar-se e adaptar-se sem contradições (Adorno e Horkheimer 1971, pp. 80-81). A negação do saber, ou seja, a abdicação da transmissão do saber historicamente construído e imposto - em nome da democratização do ensino (leia-se integração via banalização) -, é conformismo e aniquilação das suas potencialidades.

Este distanciamento da escola é caracterizado por Adorno como uma tendência imanente de erigir-se em esfera com vida e legalidade próprias. Haveria ali um certo hermetismo arredio a críticas. Este isolamento, em certo sentido, é inerente à própria cultura que, ao resgatar e cultivar o nãoaproveitável de imediato na práxis dominante, aponta para seus aspectos questionáveis. Porém o encapsulamento da escola não seria apenas ideologia ou uma virtude a ser sacralizada, mas uma "necessidade", pois

(...) uma escola que sem nenhuma sorte de travas se abrisse totalmente ao externo, provavelmente perderia também seu caráter acoIhedor e formativo. (Adorno 1972, p. 77)

Este caráter "fechado" da escola pouco se tem verificado no nosso cotidiano, já que as escolas - especialmente as públicas - estão mais e mais sendo devassadas, tornadas transparentes perante a comunidade. O quanto isso tem de democrático e transformador é consideravelmente imponderável já que - ao mesmo tempo - as escolas estão abertas a toda sorte de imposturas e violências além das inerentes à sua própria constituição. Já faz algum tempo que as escolas eram locais "protegidos" e "respeitados". Os traficantes de drogas e vândalos de vários matizes sabem bem o que isso significa. Também há que se considerar que, sob a égide da "democratização do ensino", a escola tem sido colocada estrategicamente como a barreira de contenção para as múltiplas necessidades dos mais pobres. Na tentativa de cumprir o seu papel, reduz-se ao assistencialismo e ao imediatismo. É exemplar a utilização de seu espaço para desalojados e a expectativa dos pais de que a escola se assenhore da formação dos filhos. Não menos indicativo é o estímulo dado aos alunos 
da rede de ensino municipal em São Paulo: quem vai à escola recebe uma lata de leite em pó por mês. É evidente que esta iniciativa não diz respeito apenas a interesses eleitoreiros: ela demonstra o preço que a escola tem de pagar para que seja chamada de "progressista". Se estes dados apontam para a necessidade de uma auto-reflexão crítica, também indicam o imperativo da defesa de seu espaço e de sua especificidade.

O professor e a escola como um todo, ao abdicarem de sua função em nome da "democratização do ensino" - leia-se difusão hipócrita do espírito -, consolidam a indiferenciação e o obscurantismo.

A respeito da seleção dos conteúdos conforme a realidade dos alunos - o que se costuma chamar de respeito ao "nível sociocognitivo" da clientela escolar -, o que assistimos é a uma desqualificação constante dos chamados "bens culturais". Ora são simplesmente negados por legitimarem as diversas formas de poder. Ora são neutralizados e petrificados como "clássicos" e "peças de museus", destituídos da sua vitalidade. Ora são transformados em mercadorias e confinados à pura ostentação dos pseudocultos ou banalizados ao extremo para que as massas possam compreendê-los. Ora são simplesmente silenciados porque, supostamente, não dizem respeito à realidade das novas gerações e das classes subalternas e ousar resgatá-los seria elitismo, anacronismo, tradicionalismo, no pior sentido que se pode dar a estas palavras.

Exemplar também é como a linguagem tem sido tratada nas escolas da rede pública, onde o simples grifar erros ortográficos cometidos por alunos na produção de seus textos é considerado reacionário. A complacência frente ao que Adorno chama de "dialetos dos operários" é notória, como se ainda se ventilasse dogmaticamente entre os educadores a idéia de uma "ditadura do proletariado". Para Adorno (1993, pp. 19-20), esta linguagem nada tem de revolucionária, sendo simplesmente a expressão da dominação:

\footnotetext{
Ajustando-nos à fraqueza dos oprimidos, confirmamos nesta fraqueza o pressuposto da dominação e desenvolvemos nós próprios a medida da grosseria, obtusidade e brutalidade que é necessária para o exercício da dominação.
}

Negligenciar a necessidade de escolares carentes aprenderem a falar e escrever de acordo com a "norma culta" é o mesmo que lhes dar o veredicto da marginalização sem esperanças. 
Se os nossos filhos e alunos são demasiadamente imaturos, alienados e pobres objetivamente e subjetivamente, não é com a recusa pura e simples de posturas pedagógicas e conteúdos considerados tradicionais que vamos cumprir o nosso papel de educadores. Caso contrário, continuaremos sonhando com a democratização de ensino no âmbito estrito de teorias educacionais, como tem acontecido em relação ao construtivismo.

A dicotomia entre conservadores e liberais e/ou progressistas, na História do Brasil, tem se dado muito mais na forma que no conteúdo das suas reivindicações. Silva (1993), ao tentar desconstruir o construtivismo pedagógico, aponta para a "regressão conservadora" desta teoria e prática educacional, pois entende que a "psicologização da educação implica, necessariamente, na sua despolitização" (p. 5). Apesar de um "discurso progressista", o construtivismo preserva uma concepção naturalista de infância e de desenvolvimento desconectada das condições históricas e sociais (p. 6).

A crítica de Silva se detém sobre a psicologia, mas o que está inicialmente em questão, no nosso entender, é o modo positivista de pensar e de fazer ciência. Colocar a crítica da economia política nesta discussão é fundamental, o que não significa necessariamente rechaçar explicações psicológicas. Ao contrário, mostram-se necessárias à medida que os processos de alienação e insensibilização determinados politicamente têm encapsulado o inconsciente, trabalhando pela naturalização da sociedade. Encontrar a objetividade na subjetividade talvez nos leve a um reduto ainda conservado de potencialidades transformadoras.

Portanto, se o construtivismo, mesmo se contrapondo ao ensino tradicional, termina por perpetuar a tradição conservadora na educação, isso se deve por se inscrever dentro do pensamento positivista. Combater esta inserção exige mais que uma crítica bem intencionada da sociologia, da pedagogia ou da psicologia. O nosso olhar deve se deter na matriz positivista, que permanece inclusive em certas leituras do marxismo.

\section{A crítica ao positivismo}

Ao nos contrapormos ao ensino tradicional, estamos, em primeira instância - se esta contraposição pretende ser crítica -, fazendo a crítica à ciência positivista tão cara aos manuais escolares. Portanto, uma transformação efetiva na educação requer a formulação de um conhecimento crítico articulado a uma experiência que possa romper com a ética conformista do 
positivismo que está a serviço da descoberta das leis que regem a sociedade, sem contudo almejar a sua transformação. É fundamental não perder de vista que "crítica da sociedade é crítica do conhecimento e vice-versa"(Adorno 1972, p. 149). A escola deve manter a tensão indivíduo/sociedade e estar para a realidade como a filosofia está para a ciência. Ou seja, distanciar-se para poder refletir sobre ela. É necessário romper o dogma da ciência como ritual para possibilitar o pensamento e a liberdade. Mas a escola se vê mais e mais aprisionada pela lógica do capital e à razão instrumental inerente a ela, cujo âmbito do pensamento equivale à quantificação:

\begin{abstract}
A equação entre espírito e mundo é solucionada sem deixar resto, mas devido apenas a seus dois membros serem reciprocamente simplificados. Na redução do pensar ao aparato matemático está implícita a consagração do mundo como medida de si mesmo. O que aparece como triunfo da racionalidade subjetiva, a sujeição de todo ente ao formalismo lógico, é pago com a subordinação dócil da razão aos achados imediatos. Compreender o achado como tal, notar nos dados não apenas suas relações espaço-temporais abstratas, por onde podem então ser apanhados, mas pensá-los, em vez disso, como superfície, como momentos mediatizados do conceito que só se preenchem no desdobramento de seu sentido social, histórico, humano - toda a pretensão ao conhecimento é abandonada. Ela não consiste no mero perceber, classificar e calcular, mas justamente na negação determinante do que a cada momento é imediato. Mas o formalismo matemático, cujo meio é o número, a figura mais abstrata do imediato, fixa, em vez disso, o pensamento na mera imediatez. $O$ fatual conserva o seu direito, o conhecimento se restringe à sua repetição, o pensamento converte-se em mera tautologia. (Adorno 1989, p. 19)
\end{abstract}

É evidente que o pensamento dialético está no cerne desta formulação:

A compreensão da ação recíproca que indivíduo e sociedade exercem um sobre o outro tem uma conseqüência fundamental - evitada precisamente pela sociologia positivista - na idéia de que o homem como indivíduo alcança sua existência própria somente em uma sociedade justa e humana. (Adorno e Horkheimer 1969, pp. 56-57)

Para Adorno, a dialética supera o positivismo justamente porque continua a pensar além dos limites da não questionada autoridade do empreendimento científico. "Pensar perigosamente", não retroceder peran- 
te a experiência, nem ceder perante o consenso do "previamente pensado" é imprescindível na contraposição do pensamento como mera imediatez. Para Adorno (1972, p. 14), o pensamento filosófico não se submete a esquema ou conclusões finais. Pois a filosofia não começa quando aprendemos a duvidar de convicções particulares ou gerais, de dogmas e axiomas?

O positivismo se contrapõe à dialética com o argumento de que esta última produz um conhecimento e uma crítica meramente especulativos e por isso esvaziados de sentido, contrários ao rigoroso conceito de validade científica objetiva proposto pelos positivistas. Adorno argumenta que o conceito de "especulativo" foi distorcido do seu sentido original na filosofia alemã veiculado por Hegel, ou seja, o da auto-reflexão crítica do entendimento, sendo substituído pelo que se afirma popularmente, ou seja, especulativo é o pensar futilmente, sem compromisso e, portanto, desprovido de autocrítica e confrontação com as coisas. O caráter especulativo da dialética, para Adorno, é a proposta de um pensamento que possa despojar-se de si mesmo e de sua limitação, almejando assim a objetividade nos termos de um distanciamento crítico do sujeito em relação ao objeto. Os positivistas, ao pressuporem a especulação em sentido vulgar e negativo para analisar a dialética, acusam-na de arbitrariedade subjetiva porque carece de controles universalmente válidos e objetivos. Mas o que seria a objetividade positivista que tem as contradições como anátemas perseguindo a purificação de todas as projeções subjetivas através de uma razão instrumental indiscutivelmente subjetiva? Para Adorno (1989, pp. 109-110), a objetividade positivista, ao limitar-se na contemplação de seus códigos de cientificidade e ao hipostasiar o sujeito cognoscente, é em si mesma subjetiva e especulativa no sentido pejorativo atribuído à dialética.

Esta discussão inicial nos parece fundamental, pois quem pretende realizar uma pesquisa aceitável dentro dos cânones da cientificidade tem de substituir, sem mais, o especulativo, enquanto domínio de um conhecimento pré-científico, pelo comprovável através da observação e coleta de dados. A idéia de pré-científico é um item interessante da discussão entre Popper e Adorno. Para o primeiro, pré-científico é o que ainda não atravessou o trabalho de autocrítica da ciência, até mesmo evitando-o. O conceito de pré-científico associa-se à metafísica arregimentada em pressupostos não possíveis de serem falseados e, por isso mesmo, não científicos. Adorno (1989, p. 120) argumenta que no âmbito do malconceituado pré-científico estão também a racionalidade e a experiência que, em 
nome da instrumentalidade, são excluídas. Com isso não invalida o rigor científico ao considerar que "(...) tão certo como sem disciplina não haveria progresso da consciência, é certo que a disciplina paralisa simultaneamente os órgãos do conhecimento".

A metodologia científica na concepção de Adorno é direcionada por uma tendência harmonizadora que, ao tratar a sociedade mecanicamente, escamoteia os antagonismos da realidade objetiva, limitando-se a classificá-la, reduzindo a um mesmo conceito elementos irredutíveis e contraditórios (1989, p. 118). Todo o refinamento matemático da metodologia científica converte-a no seu contrário. Ou seja, o método primordialmente enquanto meio para a elaboração teórica, para os positivistas, torna-se um fim em si mesmo banindo de seu âmbito o que pretensamente privilegia, isto é, a experiência (Adorno 1989, p. 119).

$\mathrm{Na}$ controvérsia de Tübingen, Adorno ressalta a questão da crítica em Popper que, no seu entender, é colocada de forma superficial. A crítica não deve se ater apenas nas proposições científicas, mas inevitavelmente em crítica da coisa. Por exemplo: há tanto sentido em falar de uma instituição social como das teorias que possam explicá-la. Nas palavras de Adorno:

\section{(...) De modo legítimo o uso da linguagem na crítica não visa somente autocrítica - tal como sucede propriamente em Popper - mas também a crítica à coisa. (1989, p. 124)}

A crítica dialética não se satisfaz somente com a verificação da possibilidade de mostrar a veracidade ou falsidade de hipóteses propostas, antes procura o que Adorno denomina de "transição transparente ao objeto", ou seja, a busca da expressão dos antagonismos imperceptíveis ao sistema lógicocientificista do pensamento. A idéia de sistema que os positivistas buscam estabelecer é o cerne a ser criticado pelos dialéticos (Adorno 1989, p. 125).

Popper afirma que a objetividade científica pode ser explicada somente frente a categorias como competição entre cientistas e tendências teóricas, a tradição crítica, a tolerância política nas discussões livres. Adorno problematiza estas categorias apontando para sua fragilidade. Com relação à competição, coloca a questão dos mecanismos das leis de mercado pretensamente racionais. Para Adorno (1989, p. 131), Popper parece não reconhecer as contradições da seleção na carreira acadêmica e a 
manipulação política da produção do saber científico. Este equívoco parte da concepção da sociedade enquanto objeto e não como sujeito que se autodetermina, lançando sua sombra sobre a objetividade cientificista.

Adorno, ao problematizar conceitos básicos do pensamento popperiano, tais como demarcação e objetividade científica, falsificabilidade e crítica, não pretende, no nosso entender, invalidar o saber científico, mas propor uma teoria do conhecimento que possa diferenciar-se de uma teoria da ciência, preocupando-se não somente com o aperfeiçoamento metodológico. À fetichização do método, Adorno sugere o questionamento da mitologia em que se converteu a produção científica. A dialética, colocando-se como o "outro", põe-se a serviço deste desencantamento.

Em Popper, como no positivismo em geral, a teoria do conhecimento reduz-se à teoria da ciência, ou seja, à questão metodológica, à eficiência, à afirmação do real enquanto inquestionavelmente racional. Popper é emblemático nesta discussão sobre pensamento positivista e pensamento dialético, reduzindo-se o primeiro à mera ferramenta de aperfeiçoamento do existente. Porém esta sacralização dos postulados científicos tradicionais é moeda corrente na epistemologia inerente ao processo educacional acrítico. Citar Popper é apenas um recorte epistemológico, por sinal bastante problemático devido às contradições dele com o positivismo.

O positivismo obviamente está explicitado nos currículos escolares e constitui sua própria tessitura. Interessante como as próprias pedagogias progressistas compactuam com a apreensão acrítica de saberes afirmativos. Pensar a transformação e construção do conhecimento é possível sem pensar a teoria do conhecimento aprisionada nos moldes positivistas? As teorias educacionais deveriam ter como pressuposto a sua autocrítica.

Patto (1996), em sua pesquisa sobre o fracasso escolar, questiona se os textos colocados à disposição de professores no sentido de formálos e sanar as suas dificuldades não os estariam confundindo ainda mais. A natureza do discurso científico e o seu papel na escola precisam ser pensados: as afirmações de uma ciência pretensamente objetiva e neutra - postulado básico do positivismo - eleva a ideologia à condição de saber absoluto em que educadores e educandos não conseguem estabelecer contatos reais, ou seja, experiências significativas que permitam um processo de mudança.

Patto (1996) critica as pesquisas mais recentes que se dedicam a demonstrar as deficiências cognitivas da criança a partir da teoria piage- 
tiana. Essas pesquisas chegam a conclusões que contrariam os conhecimentos acumulados pelas ciências humanas e o próprio bom senso. As provas piagetianas de conservação, seriação e classificação são aplicadas sem levar em conta os tipos de atividades que o ambiente no qual a criança está inserida pode ou não propiciar. Neste caso, aprioristicamente, determinou-se as causas do fracasso escolar através de provas "standard" (p. 342). O problema, como desenvolvemos a seguir, não se limita a uma mera recepção equivocada de teorias, na medida em que as idéias de Piaget não avançam em relação aos moldes científicos tradicionais aprisionados à utilidade concebida como verdade.

O construtivismo enquanto solução para o caos reinante na educação é discurso praticamente unânime, mas que extramuros das discussões teóricas tem se convertido em método a ser apropriado sem mais. As idéias de Piaget foram tomadas como oposição àquelas vigentes no ensino tradicional, ou seja, como negação a determinados procedimentos pedagógicos, e por isso mesmo têm sido reduzidas a procedimentos alternativos sem o aprofundamento devido em seu substrato teórico. Este fato é preocupante já que os objetivos educacionais postulados pelos construtivistas visam justamente a crítica de um pensar apenas reprodutor e, portanto, não criativo. Preocupante quando almejamos algo diferente da instrumentalização do pensamento equiparado pela ciência moderna à matemática. A compreensão do mundo nesta perspectiva só é validamente construída e expressada pelos procedimentos aritméticos e algébricos. O desenvolvimento do pensar e agir matemáticos em Piaget tem um lugar privilegiado, pois ele não se dedica apenas a demonstrar o desenvolvimento desta trajetória, mas a utilizá-la como método de pesquisa e exposição de suas conclusões.

A construção do conhecimento, no entender de Piaget (1965, p. 14), passa pela sujeição conceituada numa concepção biológica e não sociopolítica. A submissão é fonte de conhecimento. O sujeito se constituiu como tal a partir da sujeição da natureza ao pensar e agir matemáticos e do reducionismo que este procedimento implica. Contudo, a sujeição não se deu no nível do objeto simplesmente, mas do sujeito que precisou e tem precisado se sujeitar a este conhecimento para sobreviver. Em que medida esta sujeição recíproca pode ser colocada em termos de construção do conhecimento é uma questão crucial no rol das inquietações aqui arroladas.

A professora e pesquisadora piagetiana Constance Kamii, em conferência realizada recentemente na cidade de São Paulo, ${ }^{1}$ ao defender redefi- 
nições no ensino da aritmética, teceu algumas considerações a respeito do raciocínio lógico-matemático que nos situou de maneira mais confortável (ou ainda mais desconfortável) no que diz respeito à construção do conhecimento. Remetendo-se a Piaget, Kamii expôs sobre o conceito de número na criança que é construído de "dentro para fora", num processo de reinvenção da matemática. Isto porque a aritmética está nos limites do conhecimento social, ou seja, é uma convenção histórico-culturalmente construída e que diz respeito à abrangência do raciocínio lógico-matemático cuja verdade está "na cabeça de cada criança". Os conceitos numéricos não são ensináveis. As crianças não vão à escola aprender os conceitos numéricos porque os descobrem naturalmente, pressupondo-se que o raciocínio lógico-matemático é um conhecimento natural, biológico, universal. É subjacente a este discurso a idéia de um certo espontaneísmo na aprendizagem que seria fronteiriço à especulação no sentido forte. Não mais que fronteiriço, já que a especulação, neste caso, não se encontra pari passu com a reflexão: conteúdos e finalidades já são estabelecidos a priori.

Existindo a mesma matemática em toda parte - o que é possível de ser percebido nos jogos infantis cujos procedimentos e reações são similares independentemente de local, época e lugar -, Kamii sugere, então, que o ensino da aritmética deve ter como horizontes o estímulo ao desenvolvimento do raciocínio da criança para que ela possa construir em si mesma a aprendizagem da aritmética cujas regras não precisam internalizar porque já as tem. O conhecimento lógico-matemático na sua versão aritmética é um legado cultural que não deve ser colocado de uma só vez, pois a criança tem formas e momentos próprios de adquirir este conhecimento. O cerne da crítica de Kamii ao ensino tradicional da aritmética é o uso dos algoritmos que embota a capacidade de pensar. A forma racional e precisa de pensar se estabelece através de relações que exigem, evidentemente, uma descentralização do sujeito. Portanto, na construção do conhecimento aritmético, os algoritmos devem ser substituídos por jogos que são atividades interindividuais.

De qualquer forma, do nosso ponto de vista, o conhecimento a ser construído ou por algoritmos ou por jogos diz respeito antes a uma apropriação de um saber que não visa a construção, mas a instrumentalização. Aprender aritmética tanto de uma forma como da outra não é construir conhecimento, é se apropriar dele de maneira mais ou menos eficiente. Em outras palavras é se adestrar na utilização de uma ferramenta e sujeitar-se a ela. Kamii considera que para a construção do conhecimento lógico-matemático é necessário o respeito à criação. Na escola tradicional não se dá às crian- 
ças este direito. Ela não entende o que faz. Apenas aprende truques. $\mathrm{O}$ ensino da matemática tem se resumido à compreensão de "macetes", formas de operar e chegar a resultados sem que a criança possa explicá-los. Inquietanos o fato de que uma concepção epistemológica projetada sobre procedimentos pedagógicos possa contribuir para a compreensão das operações lógicas, todavia sem pensá-las num sentido amplo. Ou seja, será que basta colocar-se diante da matemática apenas com a questão "como se procede" ou, em primeira instância, "por quê" e "para quê"? Conceber o raciocínio lógico-matemático como "natural" e essência mesmo da Razão, certamente, coíbe o questionamento além do "como fazer", que neste caso pode ser avaliado como "aquém" das operações formais.

Quando a professora Constance Kamii refere-se à aquisição de "truques" a que tem se convertido a aprendizagem da aritmética, será que não pode aplicar esta crítica também ao construtivismo? Saber dos procedimentos de um mágico e também fazer mágicas pode ser bastante interessante, mas neste estágio ainda estamos no limites do ilusionismo.

A formulação de hipóteses tão cara aos construtivistas, pela qual as crianças constroem seu conhecimento, na verdade tem de ser confirmadas o quanto antes, e a maneira como são formuladas permite por parte do professor classificar este aluno - situação semelhante à associação livre na terapia psicanalítica que permite um diagnóstico e conseqüente tratamento. A especulação é colocada definitivamente como um prolongamento da atividade de classificação e assim quebrantada apenas comprova o que é sempre o mesmo (Adorno 1993, p. 59). Os construtivistas estão cobertos de razão: a construção do conhecimento para o pensamento reificado é tautologia, confirmação do que é e sempre será expressão da sua impotência.

Para Adorno, o conhecimento se dá numa rede entrelaçada de juízos, intuições, inervações, autocorreções, antecipações e exageros. Nisso, os construtivistas devem concordar: a sua complacência com o erro é bastante conhecida. Mas apenas num nível em que as contradições do pensamento que ocorrem no processo de experimentação sejam superadas na descoberta do "verdadeiro". Reconhecer estas "inervações" do pensamento e não rechaçar o erro não é suficiente:

Pois o valor de um pensamento mede-se por seu distanciamento da continuidade do desconhecido. O valor diminui objetivamente com o encurtamento dessa distância; quanto mais o pensamento se 
aproxima do "standard" estabelecido, mais ele perde sua função antitética, e é somente nela, na relação manifesta com seu contrário, não em sua existência isolada, que sua pretensão se encontra fundada. (Adorno 1993, p. 69)

Nos jogos infantis, através dos quais os construtivistas se jactam de inovadores justamente por considerá-los e incorporá-los na prática pedagógica, Adorno (1993) procura não o que há de afirmativo e idêntico ao estabelecido, mas a crítica ao mundo da produção neles implícita:

\begin{abstract}
Precisamente na medida em que despoja as coisas que manipula de sua atividade mediatizada, a criança busca salvar, em seu trato com elas, 0 que as torna benéficas aos homens e não à relação de troca, que deforma igualmente homens e coisas. O caminhãozinho não vai a nenhum lugar, e os minúsculos barris que transporta estão vazios; todavia permanecem fiéis à sua destinação não a exercendo, não participando do processo de abstração que nivela neles aquela determinação, mas ficam imóveis como alegorias daquilo para que existem especificamente. Dispersos, decerto, mas não absorvidos, aguardam para ver se a sociedade apagará um dia o estigma social que carregam, se o processo vital entre o homem e as coisas, a práxis deixará de ser prática. A irrealidade dos jogos anuncia que o real ainda não o é. Eles são exercícios inconscientes para a vida justa. (pp. 199-200)
\end{abstract}

Se as crianças aprendem brincando, isso não nos pode fazer pensar em um mundo em que trabalho não seja condenação, e divertimento apenas o refazer-se e amoldar-se para este trabalho? Os jogos infantis como exercícios para a vida justa se contrapõem àquela concepção que os vê simplesmente como exercícios para a vida adulta, injusta em muitos aspectos. Nesse sentido, os jogos infantis são utilizados o mais cedo possível para a adequação ao existente. Exemplar é a utilização de embalagens vazias para facilitar o processo de alfabetização: a leitura de mundo da criança já é adestrada à localização dos produtos nas prateleiras dos supermercados. Ou mesmo a "paixão de conhecer o mundo", que os construtivistas dizem estimular na criança, por exemplo, quando ao dissecarem um animal se pode ver como é "interessante" lá dentro do bichinho, sem se dar conta do problemático domínio da natureza. O livro $A$ paixão de conhecer o mundo, de Madalena Freire, além do exemplo citado, apresenta outras diversas situações muito ricas que podem ser utilizadas de forma mais crítica. As crianças de uma favela, segundo relato da autora, fizeram 
um minizoológico com os animais peçonhentos que atormentam suas vidas. Ora, por que os ecologistas não estariam interessados nesses animais? Por que ninguém vai ao zoológico para ver baratas e ratos? O que é uma questão de saúde pública, que deveria remeter à indignação perante as condições de vida, é entendido como adequação do método de ensino à realidade do aluno, por mais abjeta que ela possa ser. Nesse sentido, na inadequação não estaria verdadeiramente implícita a justiça a estes alunos? "É com o sofrimento dos homens que se deve ser solidário; o menor passo de diverti-los é um passo para enrijecer o sofrimento", é o alerta de Adorno profundamente urgente aos que trabalham pelo esclarecimento (Adorno 1993, p. 20).

\section{Experiência e educação emancipatória}

Interessante é que, onde os piagetianos vêem a universalidade do raciocínio lógico-matemático, Adorno evoca o pensamento e a experiência não necessariamente limitados à capacidade formal de pensar:

Em geral esse conceito de racionalidade (o da racionalidade ou de consciência) é apreendido de um modo excessivamente estreito, como capacidade formal de pensar. Mas esta constitui uma limitação da inteligência, um caso especial da inteligência, de que certamente há necessidade. Mas aquilo que caracteriza propriamente a consciência é o pensar em relação à realidade, ao conteúdo - a relação entre as formas e estruturas de pensamento do sujeito e aquilo que este não é. Este sentido mais profundo de consciência ou faculdade de pensar não é apenas o desenvolvimento lógico formal, mas ele corresponde literalmente à capacidade de fazer experiências. (Adorno 1995, p. 151)

Consideramos que, sem sombra de dúvidas, a Teoria Crítica, em particular as idéias de Adorno, tem muito a contribuir para a psicologia do desenvolvimento e à pedagogia por ela inspirada. O objetivo principal desta articulação é uma educação emancipatória, cujo projeto encontra-se limitado pelas condições objetivas. Isso não inviabiliza sua formulação e tentativas de concretização, tendo em vista que a educação ainda permanece como possibilidade de se opor à barbárie.

Adorno vincula a educação necessariamente à emancipação como seu objetivo por excelência. Entendendo emancipação como conscientização, racionalidade, Adorno não pode negar o momento de adaptação 
inerente a esse processo. Antes aponta para esta ambigüidade, ponto crucial da educação emancipatória e da construção da experiência formativa. Porém a constatação dessa ambigüidade não deve ser paralisadora, na medida em que a tarefa reservada à família, à escola, à universidade, num momento de conformismo onipresente, é a de fortalecer antes a resistência (Adorno 1995, pp. 143-144). O núcleo impulsionador desta resistência é o indivíduo, o que não quer dizer que devamos cultivar indivíduos como se cultivam plantas. Ou seja, uma educação sem indivíduos é repressiva, mas há que se estar atento para o quimérico e o ideológico do culto à individualidade (p. 154).

Em linhas gerais, educação para Adorno, numa concepção que ele considerou apenas inicial - mas que na verdade subsume as idéias que discutimos até o momento -, não é a modelagem de pessoas nem a transmissão de conhecimentos sem mais, sendo, entretanto, a produção de uma consciência inerente ao funcionamento de uma democracia e de uma formação cultural que faça jus ao seu conceito (1995, p. 141).

Não é à toa que Adorno cita a escola como instituição para surdosmudos, onde, a despeito até dos conteúdos programáticos - como adestramento no uso da fala, prestação de primeiros socorros às vítimas de acidentes de trânsito -, a capacidade de as pessoas falarem umas com as outras tem se atrofiado devido à falta de experiências dignas de serem comunicadas, de liberdade de expressão, de relacionamento (1993, p. 120). O individualismo decorrente desta "vivência", em que só as relações instrumentalizadas são possíveis, é o correspondente da incapacidade de o indivíduo se forjar (Adorno e Horkheimer 1969, p. 56).

Experiência é uma idéia central para Adorno, justamente porque ela já não se verifica na realidade. Raramente, em seus textos, ele se põe a defini-la. Como é de praxe, aponta para o que não é, para que o vir-a-ser possa ser pensado. Experiência é, portanto, desreificação:

Quanto mais complicado e refinado o aparato social, econômico e científico, a serviço do qual o corpo fora destinado, desde muito, pelo sistema de produção, tanto mais pobres as vivências de que esse corpo é capaz. (Adorno e Horkheimer 1989, p. 26)

O que se dá para o corpo, no sentido individual, é válido também para o corpo da massa amorfa: 
A regressão das massas, de que hoje se fala, nada mais é senão a incapacidade de poder ouvir o imediato com os próprios ouvidos, de poder tocar o intocado com as próprias mãos (...). (Idem, ibidem)

Esta morte da experiência é equivalente à experiência da morte, há muito banalizada. Afinal, por que se importar com a morte? Os mortos nada podem fazer e o futuro é o portador da morte. A expressão "aqui e agora" mostra com toda crueza o seu conteúdo de verdade: um passado esvaziado de sentido e um futuro sem promessas, em que todas as utopias foram nomeadas, ridicularizadas e deixadas ao esquecimento. Só resta, portanto, o presente da reificação, da pseudo-atividade em que as máquinas giram sem sair do lugar. Pode-se saber tudo do passado através da história das civilizações e até prever o futuro através das ficções científicas, da computação gráfica ou do ocultismo, tanto em moda, sem que isso possa nos subtrair da insensibilidade. Máquinas e homens processam as informações e delas nada sabem. Os mortos que se esqueceram de deitar - ou não puderam devido às exigências da produção - perguntam a quem insiste em permanecer vivo: "você se sente realizado?" que é um eufemismo àquela questão implícita: "você ainda não morreu?"

A pseudo-atividade ou ativismo, o constante movimento, em que nada pode parar, é "a garantia de que nada mudará, de que nada surgirá que não se adapte" (Adorno e Horkheimer 1994, p. 126). A multiplicidade de "movimentos" reivindicatórios, muitas vezes, desesperados, as expressões "vamos malhar!", "São Paulo não pode parar", "só não vai quem já morreu", dispensam maiores comentários.

Quando Adorno fala em experiência, o sofrimento é o fio condutor de seu raciocínio justamente porque a perda da capacidade de experienciar é a insensibilidade perante o próprio sofrimento e o do outro: "A experiência é sempre um agir e um sofrer reais" (Adorno e Horkheimer 1994, p. 82).

Só a perfeita conscientização do horror que temos pelo aniquilamento estabelece um verdadeiro relacionamento com os mortos: a unidade com eles. Pois, como eles, somos vítimas das mesmas condições e da mesma esperança decepcionada (...). (Adorno e Horkheimer 1994, p. 200)

As pessoas recalcam a história dentro de si mesmas e dentro das outras, por medo de que ela possa recordar a ruína de sua própria vida, ruína essa que consiste em larga medida no recalcamento da história. (Idem, p. 201) 
Somente no fastio dos prazeres falsos, na aversão à oferta, no pressentimento da insuficiência da felicidade, mesmo onde haja alguma para não falar da circunstância em que ela é adquirida às custas da renúncia à resistência supostamente doentia a qualquer sucedâneo positivo de felicidade - só aí haveria de germinar o pensamento do que poderia ser a nossa experiência. (Adorno 1993, p. 53)

Estas frases assim enumeradas, mesmo retiradas do contexto em que se inseriam, mostram a preocupação de Adorno e de Horkheimer com a elaboração de uma teoria do progresso e de uma relação crítica com o passado. Esta filosofia da História é fundamental para se compreender não só o conceito de experiência como a própria formulação da dialética negativa. Só pode buscar o alívio e a cura para o sofrimento aquele que o sentiu em toda sua agudeza. Ao escamotear a presença do corpóreo, tanto a metafísica quanto a teoria do conhecimento tradicional deixam escapar o momento da transformação.

A questão que se coloca então é como é possível produzir um conhecimento que rompa com a tautologia em que o pensamento ora se encontra. A possibilidade de um pensamento que rompa com um saber que se apropria da existência e a perpetua como um esquema (Adorno e Horkheimer 1989, p. 20) é o desafio da nossa época.

Não se pode negar simplesmente as conquistas humanas no sentido biológico e sociocultural, entretanto erigir-lhes um altar no sentido da naturalização e sacralização de seus procedimentos é afirmar a barbárie até então inerente à civilização. Morte aos mitos, repressão ao medo foram e continuam sendo artimanhas da razão enquanto órgão de adaptação humana. Mas, ao banir o pensamento, a razão tem fracassado no intuito de construir o sujeito, e velhos mitos com novas roupagens ressurgem. A trajetória do pensar reificado quer nos convencer de uma linearidade e um progresso no mínimo suspeitos. A razão que possibilitou a sujeição da natureza viu-se também confinada às grades que forjou na luta pela autoconservação. A cultura, espaço histórico da constituição do indivíduo, converte-se em natureza.

Ciência e tecnologia, devido às quais nos denominamos seres racionais, têm seus conceitos atrelados à gênese do mundo burguês, ou seja, à formação do capitalismo que não se limita a um modo de produção, mas se constitui numa forma de dominação. Nos séculos seguintes, o projeto burguês mais bem acabado e ainda não realizado viria à tona: o lluminismo, que deveria instaurar o cientificismo de uma vez por todas 
através do desterro da mitologia. A mitologia, na tentativa de compreender a multiplicidade, perpetrou a anulação do objeto. O postulado de Bacon da "Una Scientia Universalis", e o decorrente deste ao estabelecer o caráter universal do pensamento, liquidou, por sua vez, o sujeito. Ambos buscam o mesmo no diverso. Entre mitologia e lógica formal, o espírito ordenador traça um caminho de aperfeiçoamento e alienação.

Nesse sentido, a natureza reduz-se à aplicabilidade, por isso mesmo, ao cálculo. O que não é útil e previsivelmente controlado não pode ser pensado. A razão limita-se, assim, ao existente, impossibilitada de o contrapor. O lluminismo, em seu sentido literal, ou seja, de um pensar que faz progressos, identifica pensar e matemática. O pensamento deve curvar-se perante os números, novos ícones, originários daqueles anteriormente rechaçados como metafísica. Se os mitos pretendiam dar conta do mundo, os iluministas estabeleceram a sua matematização, já comum na Antigüidade clássica: Platão equiparava idéias e números. O procedimento matemático converte-se num ritual e o lluminismo tem, desse modo, se mitologizado progressivamente.

O lluminismo, enquanto busca do saber, do esclarecimento, da autonomia, está confinado pelo encantamento mítico, colocando-se a serviço da dominação dos indivíduos. Portanto, tem se fortalecido o seu contrário, o obscurantismo. Só poderá fazer justiça aos seus fins quando se libertar das malhas da dominação a quem tem servido.

\section{As relações interpessoais e a democracia}

A idéia de um desenvolvimento infantil em "passos sucessivos" que estão de acordo com uma "tendência inerente" à sociedade justa, com maior interação mútua em relações humanas, exige urgentemente uma teoria que leve em conta a sociedade em que vivemos, mantenedora da imaturidade e da heteronomia dos seus membros. Este "processo natural", tão caro à epistemologia genética de Jean Piaget, não pode ser hipostasiado para todos os tempos e sociedades e erigido como instrumento de democratização. Ao verificarmos, por exemplo, a afinidade entre a psicologia cognitiva de Jean Piaget e a teoria da ação comunicativa em Habermas, dificilmente podemos alinhar esta perspectiva teórica a um pensamento emancipatório.

Se alguma contribuição a Teoria Crítica pode oferecer à educação, certamente é algo que se afasta de relações imediatas entre desenvolvimento 
cognitivo e formas livres de comunicação. Como é possível pensar em formas livres de comunicação numa sociedade não livre? Podemos afirmar que Adorno desenvolveu uma teoria da linguagem ao formular textos em que o comunicável de imediato certamente não era a sua preocupação. Acusava, antes, os defensores da comunicabilidade fácil de minarem a substância crítica daquilo que pretendiam comunicar. A simplificação em nome da facilidade da comunicação é apenas a adequação às leis de mercado:

Se a opinião pública atingiu um estado em que o pensamento inevitavelmente se converte em mercadoria e a linguagem em seu encarecimento, então a tentativa de pôr a nu semelhante depravação tem de recusar lealdade às convenções lingüísticas e conceituais em vigor, antes que suas conseqüências para a história universal frustrem completamente esta tentativa. (Adorno e Horkheimer 1994, p. 12)

Portanto, não se pode falar em comunicabilidade na medida em que se perde o referencial da "substância crítica". Para Adorno, só a implacável consciência da negatividade vislumbra a possibilidade de algo melhor. Nesse sentido, as situações mais ingênuas, descontraídas e desinteressadas merecem um olhar crítico no sentido de não haver a condescendência frente à prepotência, ao crime. Uma simples e rápida conversa com um desconhecido num transporte coletivo, por exemplo, quando manifestamos acordo para evitarmos discussão, já é até certo ponto uma traição:

(...) Nenhum pensamento é imune à sua comunicação e já é suficiente dizê-lo no lugar errado num consenso falso para minar sua verdade (...) A própria sociabilidade é participação na injustiça, na medida em que finge ser este mundo morto um mundo no qual ainda podemos conversar uns com os outros, e a palavra solta, sociável, contribui para perpetuar o silêncio, na medida em que as concessões feitas ao interlocutor o humilham de novo na pessoa que fala (...). Quando, na fase mais recente, o gesto de condescendência desaparece e só o ajustamento se torna visível, é então precisamente, nesta completa ofuscação do poder, que a relação de classe disfarçada se impõe da maneira mais implacável. (Adorno 1993, p. 20)

Reafirmar a especificidade da dialética negativa e suas possibilidades de intervenção teórica na educação é fazer jus à Teoria Crítica representada por Adorno. O que entendemos, até o momento, das leituras realizadas a respeito da formação cultural, é que a missão da escola deve 
ser a de se subtrair a moldes de pensar e agir, e qualquer transformação possível não está no "ampliar", mas no modificar profundamente não só seus procedimentos, mas sobretudo sua finalidade. Se, para a burguesia em ascensão, por exemplo, na Revolução Francesa, o papel a ser exercido pela educação era muito claro, atualmente, ao experienciarmos os resultados daí decorrentes, não devemos optar entre uma escola para a barbárie ou para a emancipação. Educação para a emancipação é um imperativo categórico. Se a educação tem cumprido sua finalidade conforme definiu Kant (unicamente pela educação o homem pode chegar a ser homem) é o que Adorno claramente questiona. A ampliação da tarefa educativa como "democratização da escola", sem ter de pensar nem a democracia nem a escola, muito menos a cultura, é um atentado contra a democracia. Acusado de "elitista" por alguns críticos, Adorno está preocupado em combater os inimigos intrínsecos da democracia. Estes inimigos que a corroem por dentro são menos os neonazistas que a sobrevivência de tendências fascistas implícitas - muitas inconscientes - na democracia.

\section{Nota}

1. Novas Perspectivas para o Ensino da Aritmética, conferência ministrada pela doutora Constance Kamii, da Faculdade de Educação de Alabama-Birminghan, promovida pela Faculdade de Educação - USP, em conjunto com o Laboratório de Psicopedagogia do Instituto de Psicologia - USP, em 5 de julho de 1995.

Recebido para publicação em Março de 2000.

\section{Critical theory and educational theories: An analysis of the discourse on education}

ABSTRACT: This article discusses society and education based on the critical theory that, especially in the thinking of T. W. Adorno, postulates the interpretation and transformation of society and of the knowledge produced by it as basic premises of liberating education. A criticism of positivism and the perception of the contradictions between culture and administration are instruments for analyzing not only constructivism, but also for the discussion on the democratization of education and the formulations that establish immediate connections between interpersonal relations and democracy.

Key words: Critical theory, education, educational sociology, democratization of education, criticism of positivism 
Bibliografia

ADORNO, T.W. Consignas. Buenos Aires: Amorrortu, 1972.

. Educação e emancipação. São Paulo: Paz e Terra, 1995.

. Filosofia y superstición. Madri: Taurus, 1972.

. Intervenciones - Nueve modelos de crítica. Venezuela: Monte Ávila, 1969.

. Minima moralia, 2. ed. São Paulo: Ática, 1993.

. "Teoria da semicultura". Educação \& Sociedade, Ano XVII, n. 56, dez., 1996, pp. 338-411.

. e ORKHEIMER, M. Dialética do esclarecimento - Fragmentos filosóficos. Rio de Janeiro: Jorge Zahar, 1994.

. La sociedad - Lecciones de sociologia. Buenos Aires: Proteo, 1969.

. Sociológica. Madri: Taurus, 1971.

. Textos escolhidos. Coleção Os Pensadores. São Paulo: Nova Cultural, 1989.

CHAUÍ, M. "Ideologia e educação". Educação \& Sociedade, Ano II, n. 5, jan., 1980, pp. 24-40.

COHN, G. (org.). Theodor Adorno, 2. ed. Coleção Grandes Cientistas Sociais. São Paulo: Ática, 1994.

GADOTTI, M. História das idéias pedagógicas. São Paulo: Ática, 1995.

HORKHEIMER, M. Teoria Crítica I (uma documentação). São Paulo: Perspectiva/Edups, 1990.

PATTO, M.H.S. A produção do fracasso escolar. São Paulo: T.A. Queiroz, 1996.

PIAGET, J. Estudos sociológicos. Rio de Janeiro: Forense, 1965.

SOUZA, T.T. da Silva. "Desconstruindo o construtivismo pedagógico". Educação e Realidade, 18 (2): 3-10, jul.-dez., 1993. 